Please do not remove this page

RMIT

UNIVERSITY

\title{
The role of social networks and trusted peers in promoting biodiverse carbon plantings
}

Torabi, Nooshin; Cooke, Benjamin; Bekessy, Sarah

https://researchrepository.rmit.edu.au/esploro/outputs/9921860382401341/filesAndLinks?institution=61RMIT_INST\&index=null

Torabi, N., Cooke, B., \& Bekessy, S. (2016). The role of social networks and trusted peers in promoting biodiverse carbon plantings. Australian Geographer, 47(2), 139-156.

https://doi.org/10.1080/00049182.2016.1154535

Document Version: Accepted Manuscript

Published Version: https://doi.org/10.1080/00049182.2016.1154535

Repository homepage: https://researchrepository.rmit.edu.au

(c) 2016 Geographical Society of New South Wales Inc.

Downloaded On 2023/04/26 20:50:02 +1000 
Thank you for downloading this document from the RMIT Research Repository.

The RMIT Research Repository is an open access database showcasing the research outputs of RMIT University researchers.

RMIT Research Repository: http://researchbank.rmit.edu.au/

\section{Citation:}

Torabi, N, Cooke, B and Bekessy, S 2016, 'The role of social networks and trusted peers in promoting biodiverse carbon plantings', Australian Geographer, vol. 47, no. 2, pp. 139-156.

See this record in the RMIT Research Repository at:

https://researchbank.rmit.edu.au/view/rmit:36191

Version: Accepted Manuscript

\section{Copyright Statement:}

(C) 2016 Geographical Society of New South Wales Inc.

\section{Link to Published Version:}

https://dx.doi.org/10.1080/00049182.2016.1154535 
Title: The role of social networks and trusted peers in promoting biodiverse carbon plantings

\section{Authors:}

Nooshin Torabi $^{\mathrm{a}}$, Benjamin Cooke ${ }^{\mathrm{a}}$ and Sarah A. Bekessy ${ }^{\mathrm{a}}$

\section{Authors' affiliation:}

${ }^{\text {a }}$ Interdisciplinary Conservation Science Research Group, School of Global, Urban and Social Studies, RMIT University, Melbourne VIC 3000, Australia

\section{Authors' email addresses:}

Nooshin.torabi@rmit.edu.au

Ben.cooke@rmit.edu.au

Sarah.bekessy@rmit.edu.au

Corresponding author:

\section{Nooshin Torabi}

E: Nooshin.torabi@rmit.edu.au

Ph: + 61399250909

F: +61 399253088 


\section{Acknowledgement:}

This research was conducted with the support of funding from the Australian Government's National Environmental Science Program (Threatened Species Recovery Hub) and the Australian Research Council Centre of Excellence for Environmental Decisions. Sarah Bekessy is supported by an ARC Future Fellowship. The authors also acknowledge Greenfleet’s assistance in providing data on their environmental planting sites. 


\section{Abstract:}

Social capital has the potential to influence the success of biodiverse carbon plantings in the face of uncertainty amongst rural landholders about the need or efficacy of efforts to address climate change through tree planting. We conducted 17 face-to-face semi-structured interviews with landholders in Victoria, Australia who voluntarily participate in biodiverse carbon plantings on their land, focussing in particular on the role of social capital for understanding how 'early adopters' can advocate for programs locally. The interviews revealed the importance of social networks and the profound impact of trusted peers on the diffusion of carbon planting schemes. These social capital dimensions are especially important for shaping ongoing participation and the ways that participants become active agents in trusted relationships that influence the participation of others. Our results suggest that the positive impact of social networks can counteract doubts about the validity of climate adaptation responses like carbon planting, and enable landholders to connect the program with their existing stewardship motivations. The ability for early adopters of the program to demonstrate the physical materialisation of their plantings to others was vital to this process. We propose that targeting champions and trusted peers in local communities could accelerate the proliferation of biodiverse carbon planting schemes.

Key words: Biodiversity; Carbon farming; Biodiverse carbon plantings; Private land conservation; Social capital; Social networks;Trust 


\section{Introduction}

Sequestering carbon through tree planting has become a key element of policy efforts to limit climate change (Torres et al. 2010), given forty-five per cent of terrestrial carbon is stored in trees (Lederer 2011). In addition to storing carbon, tree planting has the potential to preserve vital ecological processes and provide suitable habitat for wildlife (Bauhus et al., 2010, Campos et al., 2005, Carswell and Burrows, 2006). Biodiverse plantations can increase habitat for native animals, function as seed banks and enhance the resilience of ecosystems against climate change and pest invasion (Crossman, Bryan, and Summers 2011; Pearce 2005). The potential for plantations to be incorporated into existing farming systems through wind breaks, riparian zones and native woodland plantations has seen the emergence of programs aimed at sequestering carbon on private land (Sabto and Porteous 2011).

Internationally, environmental plantings have become widely adopted as an element of climate change policy (Bäckstrand and Lövbrand 2006). In Australia, the majority of carbon planting programs targeting private land are voluntary, meaning they require interest and consent on the part of landholders in order to be implemented (George et al. 2012). Many carbon planting programs have been established by privately owned offset providers to offset greenhouse gas (GHG) emissions related to individuals and businesses in a non-compliance market (Hunt 2008).

Given that biodiverse carbon planting schemes are new and emerging policy instruments that are gaining social and political interest across the globe, understanding how these schemes are taken up and diffused amongst landholders is critical. Making the case to landholders for participation in a program that involves environmental plantings for carbon abatement may 
be challenging for institutions, given the potential for scepticism about the existence and severity of climate change amongst rural farming communities and what (if anything) needs to be done to address the potential consequences of climate change (Arbuckle et al. 2013; Buys, Miller, and Megen 2011; Rejesus et al. 2013; Safi, Smith, and Liu 2012). While a substantive literature on agri-environment and conservation program adoption already exists for private rural land (Baumgart-Getz, Prokopy, and Floress 2012; Rochecouste et al. 2015; Smith 2008), the complex social relations around climate change that may influence biodiverse carbon planting schemes warrant a specific analysis for understanding program adoption and diffusion in this context. It is also important to explore how the climate change focus of carbon planting schemes interacts with the diversity of existing land management and environmental stewardship motivations possessed by landholders. This can shape and even reinterpret program intentions around the stewardship experiences of rural landholders (Gill, Klepeis, and Chisholm 2010; Trigger et al. 2008).

We suggest there is a specific need for research into how the early adopters of these programs might act as agents for encouraging the wider uptake of carbon planting schemes in rural regions. The role of informal, non-institutional knowledge sharing around carbon planting programs is particularly important given the strength of existing landholder stewardship motives and a potential lack of trust in more formal advocacy from government institutions around climate mitigation and adaptation in rural areas (Liu, Smith, and Safi 2013; Robertson and Murray-Prior 2016; Safi et al. 2012; Whitmarsh 2011).

In this paper we borrow from the adoption theory tradition in research into agricultural innovation and adoption to explore the participation of 17 landholders in a biodiverse carbon planting scheme in Victoria, Australia. Following adoption theory, participation is broken 
into five phases; awareness, non-trial evaluation, trial evaluation, adoption and post-adoption (after Pannell et al., 2006). Awareness refers to obtaining information about the environmental planting scheme and understanding its relevance to the landholder. Adoption is the process of commencing tree planting and experiencing the changes through time. Postadoption in this study relates to when landholders have well-established biodiverse plantings and are experiencing their benefits. While we acknowledge that, when narrowly applied, adoption theory can be overly focused on technological innovation and blind to socio-cultural and biophysical dimensions of farming and rural life (Stephenson 2003), we use this framing for the specific purpose of teasing out the relevance of certain phases of landholder adoption - namely post-adoption - for creating awareness and adoption amongst other rural landholders. We aim to soften the instrumental dimensions of adoption theory by focusing on how social capital, in the form of social networks and trust relations, might serve as the mechanism for enabling early program adopters to become active agents for program proliferation in this post-adoption phase amidst existing stewardship motives and potential climate scepticism.

\section{Landholder stewardship and social capital}

In exploring landholder participation in a biodiverse carbon planting program, it is important to recognise the underlying stewardship and land management motivations already present in rural communities (Cooke and Lane 2015; Gill et al. 2010; Gill 2013). Here we adopt a broad definition of stewardship, acknowledging that a desire to be a custodian of the landscape is often bound-up with a desire to be a steward of farming traditions associated with productive agriculture, like animal husbandry and pasture management (Gill et al. 2010). In this sense, initiatives that offer tree planting on private property (whatever that program's intention) 
must accommodate a landholder stewardship ethic that encompasses a mixture of primary production, biodiversity conservation and land rehabilitation objectives (Measham 2007; Smith 2008).

The emergence and persistence of stewardship amongst rural landholders is shaped by both the tangible experiences of ecological change and the social interactions that occur as part of everyday rural life (Cooke and Lane, 2015; Harrington et al., 2006).The stories, knowledge and experiences of others, including family, friends and neighbours, can all shape the stewardship trajectory of individual landholders (Gill 2013; Knapp and Fernandez-Gimenez 2009). These social-ecological interactions around stewardship perspectives will likely direct the way rural landholders interpret the potential value and contribution of carbon planting programs for their property (Riley 2006). It might be anticipated that early adopters of carbon planting schemes have a close alignment between their land management and stewardship motives and the intention of the program (Fischer and Bliss 2009). We are interested in whether early adopters can be effective agents for program diffusion through their social networks and interactions in the face of a diversity of stewardship aspirations and uncertainty about climate change and its impacts.

Social capital has gained increased attention in recent decades for its role in shaping the outcomes of community-based natural resource management (CBNRM) programs (Fukuyama, 1995; Sutherland and Burton 2011; Fisher, 2013). Here ‘social capital’ refers to how community members benefit from their relationships with others and how this further generates group benefits (Adger 2013). Private land conservation policies in particular have 
been shown to benefit from investing in the multiple aspects of social capital to increase landholder participation in conservation practices. These include 'bonding' (peer to peer), 'bridging' (landholders and their community) and 'linking' (landholders and agencies) social capital (Putnam 1993) in (Mills 2012). Building capacity for CBNRM has meant strengthening existing social capital at all three levels; for example, Landcare in Australia plays a role in assisting landholders to learn about new land management practices and acting as a conduit for communication with other landholders and environmental professionals (Campbell 1995; Compton and Beeton 2012; Curtis et al. 2000; Curtis, Shindler, and Wright 2002; Sobels, Curtis, and Lockie 2001). Our aim is to build from this literature to explore the role of bonding social capital in particular, for overcoming any hesitancies about participating in new and emerging carbon based schemes.

The two elements of social capital that we focus on here are social networks and trust. Social networks are an important component of social capital (Abbott and Freeth 2008; Almedom 2005), with research illustrating that feeling connected to the community facilitates farmers to better support climate change adaptation policies (Hogan et al. 2010). Bodin et. al (2006) argue that social networks are important in coordinating actions in natural resource management. Strong social networks make it more convenient for the landholders in regional areas to access information regarding land conservation issues (Prell, Hubacek, and Reed 2009). Trust is also a key characteristic of an effective social network (Bodin et al., 2006). While trust is a 'very complex concept' (Abbott and Freeth, 2008 p. 875), understanding trust and how agents interact is an essential part of any study on the role of social capital and managing natural resources (Prell et al., 2009). Farmer-to-farmer interaction has a profound impact in accepting a new innovation (Tarnoczi and Berkes 2009). In the natural resource management context, trust has been mainly studied as the relationship between community 
and agency and how building trust could result in more effective involvement in conservation schemes (Smith et al., 2013; Meadows et al., 2013; Lachapelle and McCool, 2012). In addition, trust happens in social networks as actors know each other directly or through a known social structure (Pretty and Ward, 2001). The interpersonal characteristics of individuals have an impact on their risk-taking and trusting behaviours in the relationship they have with natural resource management agencies (Smith et al. 2013).

Ability, benevolence and integrity are described as elements that make people trustworthy (Mayer et al., 1995). The ability to demonstrate successful outcomes of a practice, being caring and fair (Fisher 2013) and credible (Sharp et al. 2013) are essential components of a trusting relationship. Institutions have used contractors or local landholders who are trusted by the community to help attract landholders to conservation schemes, as they are more likely to trust the information they receive (Breetz et al. 2005). Landholders may also want to see the program implemented elsewhere in their community to be sure it will be implemented as it is represented before they participate (Pannell et al. 2006). These points suggest the importance of understanding how similar social dynamics work in the context of tree planting schemes that relate to carbon sequestration.

It is important to also highlight that social networks are not always encouraging or positive (Sobels et al., 2001); social networks can have negative impacts on program uptake if neighbours or other community members with constant interactions are sceptical about a specific program (e.g. soil conservation practices) or policy (Willy and Holm-Müller, 2013). In addition, social networks can have negative impacts by 'imposing normative restrictions' on actions that could benefit both community and environment (Coleman, 1988; Sutherland 
and Burton, 2011 p.239). For this reason it is vital that we explore social networks' function across conservation programs targeting issues that can be divisive, such as climate change.

Following the methodology we continue by exploring how trusted peers in a social network help in the introduction of biodiverse carbon planting initiatives to other landholders. We also examine whether trusted peers are central elements in determining the effectiveness of programs in the post adoption phase and how landholders consider those peers as a source of advice through their participation journey, in favour of maintaining contact with program coordinators. To conclude, we reflect on the research and policy implications of our findings and future opportunities for research.

\section{Methods}

\section{The study area}

Our case study is based in Victoria, Australia. Over 60 per cent of Victoria is privately owned (SoE 2013). Of this, some 80\% of tree cover has been lost (SoE 2008). Many threatened species only occur on private land with approximately $29 \%$ of known threatened species populations occurring on such land tenure (Department of Sustainability and Environment 2011). The remaining vegetation continues to experience pressures from land use alteration including agricultural intensification (both demand and profit driven) and expansion of the urban fringe (SoE 2008).

\section{Sampling procedure}

We recruited research participants for our case study through Greenfleet, a not-for-profit environmental organisation in Australia (Greenfleet 2012). Landholders were eligible to be involved in the Greenfleet program on the basis of the ecological suitability of their property 
for revegetation; this required a preliminary investigation of their property. Landholders require undertaking weed and pest control, fencing prior to revegetation. They also keep their livestock out of the revegetated areas for five years. Greenfleet undertakes regular carbon monitoring and replants trees in case of fire or drought. Financial incentives in the form of direct payments were not offered to landholders through this program. Greenfleet has established native biodiverse trees on 73 privately-owned sites across Victoria, belonging to 47 different private landholders. Landholders range from dairy, livestock, sheep (wool) farmers and cropping farmers to lifestyle and tourism property owners. Some private landholders own small farms, so called lifestyle landholders, and some are commercial landholders; there is also a group of hybrid properties. As a result, a broad spectrum of private landholders was included in the study. The focus of this study was on those landholders who adopted the voluntary biodiverse carbon planting through Greenfleet; we chose not to explore the experiences of non-adopters, given our focus on how trust and social network shape ongoing participation. Figure 1 highlights the four Victorian Catchment Management Authorities (CMAs) in whose areas the interviews took place.

\section{Please insert Figure 1 here}

\section{Data collection}

Initially, questionnaires were distributed to landholders $(n=47)$ as they provide a broad understanding of the participants in the research sample. Survey participants $(n=17)$ interested in one-to-one interviews were requested to contact us. To obtain an in-depth understanding of the role of social capital and trust in social diffusion of a program among the landholders, 17 face-to-face taped interviews were undertaken on the properties of landholders between January and September 2013. The semi-structured interviews aimed to 
capture people’s lived experiences (Holstein and Gubrium, 2003). The interviewer also walked/drove through participants’ properties, gathered field notes and spent time in their 'naturalistic’ setting (Cooper et al., 2009). Landholders had the opportunity to guide the research encounter, with participants occasionally preferring to walk around their property and identify important sites for discussion, while some preferred to conduct the formal interview at the outset. This helped to gain a better understanding of their sentiments towards the carbon plantings which could not be explained during the formal interview.

Verbatim transcriptions of interviews were undertaken, coded and studied in NVivo 10 qualitative analysis software (QSR International 2012). Data analysis was informed by a thematic approach (Boyatzis 1998) which helps to discover and present the patterns found in the interviews (Braun and Clarke, 2006). The themes emerged from the interviews through 'careful reading and re-reading of the data' and identification of main categories (Rice and Ezzy, 1999 p.258). The data analysis process was undertaken by the lead author of this study but other authors were actively involved in the discussions and development of key themes during the coding process. We specifically looked for themes related to the landholders' experiences in each stage of the program; awareness, adoption and post-adoption (Pannell et al. 2006). We started coding the interviews after the first interview had been conducted. Interviews continued until we reached the data saturation point (Glaser and Strauss, 1967) where no new themes were emerging. Confidentiality has been considered throughout this research process by giving participants pseudonyms. We have removed any town or specific place names that can make the participants identifiable. 


\section{Results}

In our results we have contracted the five broader phases into three to allow us concentrate on post-adoption given the focus on this phase for our research. As a result, we combined the findings of awareness and persuasion ('non-trial evaluation') and report these findings as one phase ('awareness'). In addition, the findings of trial evaluation and adoption are grouped as the 'adoption phase'.

\section{Awareness Phase: Receiving information from social networks and trusted peers}

In this study, three sources of receiving were observed as conduits for landholders to gain knowledge and persuasion to participate in environmental plantings. This includes trusted peers, community-based natural resource management and media. As we will discuss, trusted peers and a strong social network were the main sources of raising awareness and overcoming the general scepticism among rural communities about climate change and its mitigation and adaptation programs introduced by government agencies.

\section{Elements of trust in the social network}

A 'highly centralized network' (Bodin and Crona 2009) was observed in two of the study areas. The centre of this network (which goes beyond CMA boundaries) is a well-known landholder in the area who has been very active in land conservation practices and signed up to the Greenfleet program three years after it was rolled out and was one of the first to adopt it in his district. John, who is considered a trusted peer in his network, stated that the trust has built up as he has been a consistent and long-term member of his social network and has demonstrated successful land conservation practices on his property: 
So our family's lived in this area since the 1860 s ... So a long time. So most of these landholders I've known... I've sort of grown up with them and known of them or known them all my life. So that's the connection ... the personal connection.

Local landholders trust John as he demonstrates characteristics such as ability, benevolence and integrity (Mayer, 1995). Steve was one landholder who noted these trustworthiness characteristics when discussing being approached by John to consider entering the carbon planting scheme.

I was approached by John who is a local guy. ... John came along and said, "Let's plant trees," and I said,"Yeah, let's plant trees." So that's what we did. ...I just see John as a very trustworthy person, and he's not out to take me down, and I just sort of ... Let's go ahead with it.

Steve wanted to plant trees as the old plantation he had was burnt out in a fire and John's suggestion encouraged him to replant that vegetation through the Greenfleet. This decision was made easier by John's trustworthiness, which helped to overcome any uncertainty Steve had about the program. Noah and Linda mentioned that John helped raise awareness and connect them to the scheme.

It was a neighbour who put us onto this Greenfleet, well, put Greenfleet onto us. The Greenfleet came through the area and they spoke to one of our neighbours first, and John rang me up.

Another landholder in the region, Ryan, mentioned that trust in the person introducing a new scheme is an essential element in the acceptance of it. '...That is the nature of human beings, you need to know someone and trust them to participate in the schemes...' Aside from any 
scepticism about climate change impacts, the long-term commitment associated with some carbon planting initiatives means that the advice of trusted peers is of greater importance than in other private land conservation schemes. As a legal element of carbon planting the permanence rule exists and some plantings must remain on the properties for 100 years (Bradshaw et al. 2013). It is a permanent land use change and requires significant motivation for adoption; especially, compared with other revegetation activities like farm forestry, which has a 10 year commitment for landholders (Barlow and Cocklin 2003). Long-term issues like survival rates of plants, fire risk and increased pest animals (rabbits) as a result of habitat creation are among the concerns landholders raised regarding this program. Experienced, trusted landholders who adopt a scheme become critical agents for encouraging others to participate in such a circumstance.

\section{Value of local knowledge}

Furthermore, trusted friends and neighbours (who are not part of the scheme) are another source of recommendation. Landholders tend to trust their friends’ professional knowledge and view their knowledge as legitimate. When Laura was asked where she seeks information regarding the conservation activities on her property she responded,

...It's handy for me, the fact that one of my friends... she used to work at DSE (State government environment department) and you know she was the one who suggested the revegetation and how to go about it in the first place, so she's a bonus.

Landholders also mentioned the value of local knowledge and local contacts (networks) as a means of program awareness. In response to the question of how Luke came across Greenfleet, he responded: 'There’s a fellow locally who works for them (Greenfleet), so we have got contact through them.' Having people within your social network with knowledge 
of your land management interests meant these peers were able to connect their awareness of the scheme to participants’ existing stewardship motives.

\section{Overcoming uncertainty}

Overcoming uncertainty about program participation appeared to be driven by two primary factors: stewardship values that were not directly related to program intentions, and trusted peers who were already enrolled in the program, or who had knowledge of landholders' stewardship and were able to recommend the scheme. Stewardship values and motivations like biodiversity conservation assisted landholders in undertaking planting. "Well probably the main benefits are biodiversity benefits. So we've got a sort of a commitment and a desire to see conservation and agriculture both working” (John). John explains that balancing agriculture productivity or amenity benefits with conservation seems critical to landholders. Like many other landholders, he also recognises agriculture as an 'ecological enterprise’ (Saunders and Walker, 1998) that requires caring for the land.

In addition, the advice of a trusted peer allowed some landholders to overcome their concern about government policies and the existence of climate change. The following quotes by two of the study participants exemplify climate change scepticism and lack of trust in climate change-related policies from government.

Steve said, '... I am not convinced by the fact that climate change exists but if it is true I have done something that my grandchildren and your children will see the benefits...'.

When Andrew was asked about his opinion of carbon planting initiatives in Australian, he mentioned, '... Every day we hear about (climate change), and she [former prime minister]... talked big about this carbon trading and all that... Nothing's happened.' 
The localised experience of weather cycles and long temporal arc of climate change are perhaps a partial explanation of the attitudes noted above (Connor and Higginbotham 2013; Knapp and Fernandez-Gimenez 2009). Most pointedly, however, was that uncertainties landholders had about participation could not easily be overcome through engagement with the agency offering the scheme. They needed a change agent outside the organisation with whom they were familiar to help overcome their doubts about participation.

To move from the status quo and undertake permanent revegetation activities on private land on the recommendation of a well-known and trusted local community member seems to have been essential for the participants in this study. Overall, 14 of 17 interviewed landholders stated that they pursued carbon planting schemes as a direct result of recommendations through their social networks.

\section{Implementation (Adoption) Phase:}

\section{Elements of trust in the social network}

The adoption phase is a 'continuous process' (Pannell et al. 2006). It is a learning space for landholders and given the presence of a locally trusted peer they have the assurance that there is always someone to rely on and seek answers from regarding their plantations. The interviews reveal that the trusted peer's presence is more efficient than the support provided by the responsible agencies. Some of those agencies (e.g. local CMAs) may be local but the fact that a landholder's perception of distance is not just physical but also a social relation (in terms of how well they know the knowledge source), makes the trusted peer’s role critical. This is because of the perception of 'ability' and 'benevolence' concerning trusted peers on the part of participants, as well as the value of their local landscape knowledge. Landholders did not mention that they sought advice from the relevant local government authorities. Steve 
stated, 'Anything to do with this [biodiverse carbon plantings on his property], John's always looked after.’

David thinks that landholders who do not have access to a trusted peer need to seek agency advice but he has the opportunity to rely on John in the implementation phase of the program.

John can do ours. So you'd probably have to be slightly more in touch with the Landcare group to find out what's going on, but I don't have to because John's there. So it's a bit easy, a bit easy.

Ryan and Owen also knew John as a great source of information along the way. 'There's definitely people who are more leaders in that field but we would ask John questions definitely.' It gives them the confidence and assurance that the continuous support exists during the adoption phase. In addition, it reveals that the element of trust distinguishes John from other experienced landholders in private land conservation.

While John represented a clear example of a central point in a social network, there were a number of other landholders who proved to be similarly influential trusted peers in their social networks in other CMAs. As George (one of the influential trusted peers in his network) reflected:

We have strategically re-vegetated to link the three main patches of bush and encouraged all our neighbours to do the same... Many different groups have taken that project [a specific landscape connectivity project] on over the years and people are still re-vegetating, particularly steep gullies to contribute to that. 
As a trusted peer, George advocates not only carbon plantings but also other private land conservation practices. His practices here are also relevant to the post-adoption phase $-\mathrm{a}$ point we return to later.

\section{Value of local knowledge in a social network}

In response to a question about how the mix of species for a planting was chosen, Laura noted, ‘...Look, I basically left it to Elle. Like she knows this area very well and you know she knew my paddocks quite well.' Elements of understanding and the value of local knowledge could be observed in Laura and Elle's relationship. Luke mentioned that his social networks, including friends and neighbours, are a great source of information.

Friends and neighbours are doing a lot of work as well. We get together and discuss

it, have a look at what they're doing and what I'm doing and learn from one another.

This relationship revealed the importance of local knowledge and trusted peers at different stages of program adoption, not only the awareness phase.

\section{Post-Implementation Phase: Dissemination of the practice by landholders}

Once the biodiverse carbon plantation is well established, landholders who were not amongst the earliest of program adopters start suggesting the idea to other landholders in their social networks. The 'roll-out' of a carbon planting scheme is necessarily an ongoing project, as more landholder participants are sought to achieve the biodiversity enhancement and carbon reduction goals that are required through the continued operation of the scheme; continually recruiting new participants is therefore vital for achieving program goals. 


\section{Building trust characteristics within and outside the social network}

Early adopters in a scheme can become agents who either help or hinder the broader uptake of such a program, as they are likely to share their experiences with others - good or bad. Noah and Linda mentioned:

...I've spoken about it to my friends and neighbours and that we're very happy with the planting and it's lifted the block and we've certainly made it known amongst our friends and neighbours that we're happy with it...Quite often they [Greenfleet] bring people to see how our block looks and they believe this one of the most successful plantings they've ever seen.

The opportunity to observe the progress of existing participants before deciding whether or not to participate can be critical in voluntary conservation schemes (Tarnoczi and Berkes 2009). It is a living example that helps defuse fear by allowing landholders to observe success stories. For this reason, George promoted the importance of showing other landholders how well early plantings were doing through property:

We do two-hour farm walks, which gives people the opportunity of showcasing their properties, and that's been extremely popular....We're in a district where the attitude towards trees has certainly changed enormously over the years.

This highlights the importance of being able to see the physical manifestation of program participation for reassuring potential participants that, whatever their feelings about climate change or government initiatives, they can 'reinterpret' (Trigger et al., 2010, p1070) the program to achieve their wider stewardship aspirations. 
As landholders start to introduce the scheme to other members of a community (within or outside their own social networks) a more decentralized social network which includes a mix of actors starts to take shape that will help the longevity of the program. Oliver is another landholder who promotes the program by having open days at his property. 'We have had two and a half thousand people come through the farm for tours and stuff, so by default we have [promoted the program].’

The early adopters see themselves as champions in their community once trees are wellestablished. George thinks that he needs to advocate his success and the environmental mindset among other landholders by educating them.

We have a philosophy that we believe in sustainable land use, so we're working towards that all the time...So I work with a wide range of people, trying to educate and try to foster that sort of view.

This opportunity provides a transition for some participants from a trustor to a trusted peer (Sharp et al. 2013) in the program's proliferation. This transition can happen as a result of gaining more certainty and experience about the scheme, and demonstrating successful outcomes of the scheme to other landholders.

\section{Time: Transferring from awareness to adoption and post adoption}

When landholders became aware of the program through the trusted peers in their social networks, the decision to adopt the scheme was often straightforward. Ryan stated "I think it was pretty instant" and Noah and Olivia reflected that "We decided pretty much straightaway”. Once landholders adopt the practice, they suggest it to their neighbours and close friends because they have already experienced how the administrative process works 
for them and how it could fit their property management and stewardship goals. At this point landholders were generally satisfied with the process. As Daisy reflected:

I know when we've had different people here and they've sort of looked at our plantings and said, oh wow what a lot of work you've done, and we've said, no, we didn't plant them ourselves, you know, we had this great opportunity where Greenfleet wanted land, they would provide all the labour. We wanted the trees, the trees cost us nothing. And they went wow! How did you get onto that?

To build the confidence to recommend plantings to a broader public and social network, time may be required for trees to mature and for landholders to feel comfortable about demonstrating their success to others. Apart from the element of confidence, credibility and ability to deliver the successful outcome matters greatly to landholders. Hence, at least three to five years (depending on the ecological characteristics of each landscape) may be needed until trees are mature enough to demonstrate the type of 'ability' referred to in the literature on trust in social networks (Mayer et al. 1995).

We've had field days here; people come to have a look to see what we've done and why we've done it. So yeah, we've had probably three or four of them here. And it's getting the word out there too. It's a matter of getting it out to people.... Mat

A number of landholders mentioned that field days are a great way to introduce the scheme and to demonstrate their success to others.

\section{Overcoming negative perceptions through social networks}

Although some of the participants encountered negative community perceptions of revegetation in agricultural land, the positive influence of their social networks allowed them 
to overcome this negativity, leading to program adoption. Noah and Linda reflected on the public perception of their plantation that: ' The vast majority of them probably wouldn't necessarily approve of it because we've probably taken up 60 acres that otherwise could have been grazed'. Daisy had comments from neighbours about the change of land use she has undertaken on her property. '...I think we did have the comment that it was a very good cropping paddock and what a shame that it was now (revegetated)'. Social networks encouraged landholders to participate in a tree planting scheme in the face of any negative perception in farming communities’ towards revegetation.

\section{Discussion}

While much of the literature around trust in natural resource management focuses on the relationship between communities and government or non-government agencies (Lachapelle and McCool 2012; Meadows et al. 2013; Uphoff 1993), this study explored trust among community members within a social network. Trust in this context can play a role in driving the acceptance of novel interventions, such as biodiverse carbon plantings, showing some potential for informing future policy development. Further, previous research has mainly focused on awareness and adoption phases (Riley, 2006; Tarnoczi and Berkes, 2009). We confirm many of the findings regarding the positive role of trust and social networks in the awareness and adoption stages of conservation programs, but extend the literature on the post-adoption phase, which is important in sustaining the new practice among communities. The adoption theory framework assisted us in unpacking the importance of social capital in different phases of program participation. The nature of assistance that landholders received 
from their trusted peers differs as time progresses, which adoption theory helped us to illustrate.

Our study reveals the importance of social networks in mobilising program uptake, facilitating the provision of information about carbon plantings to potential participants. Furthermore, social networks assisted landholders in the implementation phase and subsequently encourage participants to become agents themselves in recommending the scheme to others in their networks. This resonates with research on social connectivity and its impact on rural communities' adaptive capacity towards climate change impacts (Lemos et al. 2013).

Trusted peers are one of the key players in transferring knowledge within a network of people. Peers were shown to be more popular than agencies; even a local agency can be less favoured than a trusted friend who demonstrates enough knowledge about their properties. This confirms results of other studies that have demonstrated the importance of local knowledge and proximity (Bathelt et al., 2004; Meesham, 2007; Moore and Westley, 2011) for program uptake.

This study builds on research about the trustworthiness characteristics described by Mayer et al. (1995): ability, benevolence and integrity. Trusted peers were either well known in the area and had demonstrated a history of successful land conservation practices (ability) or friends who have academic and local knowledge of the landscape (benevolence and ability). The continuous presence of the trusted peer and trusting relationship provides the participants with the assurance that there will be someone to help if any questions or issues arise during the process (integrity and benevolence). Once landholders demonstrate a successful outcome of carbon plantings, they can showcase their successes (ability) to other landholders and build 
a decentralized network which is more sustainable for program proliferation over time (Reed et al., 2009).

The ability to 'showcase' established plantings to prospective participants revealed the importance of social networks and trusted peers for demonstrating how the plantings can be achieved in ways that satisfy their wider stewardship motives. In this sense, the materialisation of the program through plant growth and the sharing of the experience of program participation aligned closely with the social relations and experiential practices that inform landholder stewardship (Cooke and Lane 2015; Gill et al. 2010). This process appears important for overcoming climate scepticism, which not only shows how the 'messenger may be as important as the message' (Safi et al. 2012, p1056) concerning advocacy around carbon planting programs , but also the setting and time at which that message is delivered (Liu et al. 2013). For this reason the post-adoption phase of current participants, when plants have established, is particular important for influencing prospective participants.

Our findings have potential implications for the future design of policies for biodiverse carbon plantings and other environmental initiatives targeting private landholders. As we have shown, paying attention to champions (trusted peers) in the community can assist in the introduction of new schemes (Van Noordwijk et al. 2011). Actively engaging with champions in local communities can enable environmental organisations to increase awareness and willingness to participate in biodiverse carbon planting schemes through the social networks of existing participants. This is especially important when there is the potential for landholders to doubt the need or legitimacy of a program.

Government agencies should identify where strong social networks already exist and preferentially introduce programs in these areas. Trusted peers, like John in this study, can 
assist the uptake of schemes and can improve implementation by providing advice postadoption, particularly when landholders might be reluctant to seek out the coordinators of programs for advice and assistance. Building social capital in regional areas, strengthening existing networks and organising open days in properties for other landholders to observe onground activities will assist the efficient delivery of related policies.

\section{Conclusion}

In addition to the 'bridging' and 'linking' social capital (Mills 2012), social networks and trusted peers within them have an important role in the diffusion of innovation. Of course not all networks produce a positive outcome. It can be hard to introduce a new land conservation practice in areas where public perception of an innovation is negative and the majority of the landholders in a network are reluctant to participate. To achieve a better outcome in programs like the one studied here, the emphasis on the role of trust and trusted peers within a social network is essential. It is gradually being recognised by researchers and policy-makers that targeting ‘local champions’ for participation, who are a source of advice and guidance in a given community, may help to ease the participation concerns of landholders who are potentially sceptical about initiatives related to climate change (Liu et al. 2013).

We found that a trusted peer in a community could aid other landholders in their network to understand how a carbon planting program can be implemented in a way that meets the existing stewardship and thus overcome their uncertainties about the programs' stated objectives. As program implementation evolves, transition from trustor to trusted peer was observed among some of the interviewees who then acted as agents to recommend the scheme to others within their social networks. In light of our exploratory study, further research is needed, which should encompass the social mapping of opportunities for 
implementing biodiverse carbon planting. There is a need to explore the various dynamics associated with rural communities that might mean they are more or less likely to take up schemes, considering factors like the strength of their social networks. This will require a detailed quantitative social network analysis to examine how landholders as social actors relate to others in their network.

In conclusion, designing policies that recognise existing stewardship and make better use of social networks and trusted peers for promoting and supporting participation in biodiverse carbon planting programs may provide an opportunity for improving program outcomes, ultimately enhancing biodiversity conservation and greenhouse gas abatement. 


\section{References:}

Abbott, S. \& Freeth, D. (2008). 'Social capital and health: starting to make sense of the role of generalized trust and reciprocity', Journal of Health Psychology 13(7) pp. 874-83.

Adger, W., N. (2013). 'Social capital, collective action, and adaptation to climate change', Economic Geography 79(4) pp. 387-404.

Almedom, A. M. (2005). 'Social capital and mental health: an interdisciplinary review of primary evidence', Social Science \& Medicine (1982) 61(5) pp. 943-64.

Arbuckle, J. G, Prokopy, L. S., Haigh, T., Hobbs, J., Knoot, T., Knutson, C. Loy, A., Mase, A.S., McGuire, J., Morton, L.W., Tyndall, J. \& Widhalm, M. (2013). 'Climate change beliefs, concerns, and attitudes toward adaptation and mitigation among farmers in the midwestern United States', Climatic Change 117(4) pp. 943-50.

Bäckstrand, K. \& Lövbrand, E.( 2006). 'Planting trees to mitigate climate change: contested discourses of ecological modernization, green governmentality and civic environmentalism', Global Environmental Politics 6(1) pp. 51-71.

Barlow, K. \& Cocklin, C. (2003). 'Reconstructing rurality and community: plantation forestry in Victoria, Australia', Journal of Rural Studies 19(4) pp. 503-19.

Bathelt, H, Malmberg, A. \& Maskell, P. (2004). 'Clusters and knowledge: local buzz, global pipelines and the process of knowledge creation', Progress in Human Geography 28(1) pp. 31-56. 
Baumgart-Getz, A., Prokopy, L.S. \& Floress, K. (2012). 'Why farmers adopt best management practice in the United States: a meta-analysis of the adoption literature', Journal of Environmental Management 96(1) pp.17-25.

Bodin, Ö, Crona, B. \& Ernstson, H. (2006). 'Social networks in natural resource management: what is there to learn from a structural perspective?', Ecology and Society 11(2).

Bodin, Ö. \& Crona, B.I. (2009). 'The role of social networks in natural resource governance: what relational patterns make a difference?' Global Environmental Change 19(3) pp. 366-74.

Boyatzis, R. E. (1998). Transforming qualitative information: thematic analysis and code development. Thousand Oaks, CA: Sage Publications.

Bradshaw, Corey J. a. et al. (2013). 'Brave new green world - consequences of a carbon economy for the conservation of Australian biodiversity', Biological Conservation 161(2013) pp. 71-90.

Braun, V. \& Clarke, V. (2006). 'Using thematic analysis in psychology using thematic analysis in psychology', Qualitative Research in Psychology 3(2) pp. 77-101.

Breetz, H. L., Fisher-Vanden, K., Jacobs, H. \& Schary, C. (2005). 'Trust and communication: mechanisms for increasing farmers' participation in water quality trading', Management Review 81(2) pp. 170-90. 
Buys, L., Miller, E. \& Megen, K. (2011). 'Conceptualising climate change in rural Australia: community perceptions, attitudes and (in)actions', Regional Environmental Change 12(1) pp. 237-48.

Campbell, A. (1995). 'Landcare: participative Australian approaches to inquiry and learning for sustainability', Journal of Soil and Water Conservation 50(2) pp. 125-31.

Coleman, J. S. (1988). 'Social capital in the creation of human capital', American Journal of Sociology 94(Suppl) pp. 95-120.

Compton, E. \& Beeton, R.J.S. (2012). 'An accidental outcome: social capital and its implications for Landcare and the 'status quo", Journal of Rural Studies 28(2) pp. 14960.

Connor, L. H. \& Higginbotham, N. (2013). 'Natural cycles' in lay understandings of climate change', Global Environmental Change 23(6) pp.1852-61.

Cooke, B. \& Lane, R. (2015). 'How do amenity migrants learn to be environmental stewards of rural landscapes?', Landscape and Urban Planning 134 pp. 43-52.

Cooper, S., Endacott, R. \& Chapman, Y. (2009). 'Qualitative research: specific designs for qualitative research in emergency care?', Emergency Medicine Journal 26(11) pp. 77376.

Crossman, N. D., Bryan, B.A. \& Summers, D.M. (2011). 'Carbon payments and low-cost conservation', Conservation Biology 25(4) pp. 835-45. 
Curtis, A., M. Van Nouhuys, W. Robinson, \& MacKay, J. (2000). 'Exploring landcare effectiveness using organisational theory', Australian Geographer 31(3) pp. 349-66.

Curtis, A., Shindler, B \& Wright, A. (2002). 'Sustaining local watershed initiatives: lessons from Landcare and watershed councils', Journal of the American Water Resources Association 38(5) pp. 1207-16.

Department of Sustainability and Environment. (2011). “BushTender.” 2012(4 April). Retrieved (http://www.dse.vic.gov.au/conservation-and-environment/biodiversity/rurallandscapes/bushtender).

Fischer, P. \& Bliss, J. (2009). 'Framing conservation on private lands: conserving oak in Oregon’s Willamette Valley.' Society \& Natural Resources 22(10) pp. 884-900.

Fisher, R. (2013). 'A gentleman's handshake: the role of social capital and trust in transforming information into usable knowledge', Journal of Rural Studies 31 pp. 1322.

Fukuyama, F. (1995). 'Social capital and the global economy', Foreign Affairs 74(5) pp. 89103.

George, S. J., Harper, R.J., Hobbs, R.J. \& Tibbett, M. (2012). 'A sustainable agricultural landscape for Australia: a review of interlacing carbon sequestration, biodiversity and salinity management in agroforestry systems', Agriculture, Ecosystems \& Environment 163 pp. 28-36. 
Gill, N. (2013). 'Making country good: stewardship and environmental change in central Australian pastoral culture', Transactions of the Institute of British Geographers 39(2) pp. 265-77.

Gill, N., Klepeis, P \& Chisholm, L. (2010). 'Stewardship among lifestyle oriented rural landowners', Journal of Environmental Planning and Management 53(3) pp. 317-34.

Glaser, B., \& Strauss, A.L. (1967). The discovery of grounded theory: strategies for qualitative research. Chicago: Aldine Publishing Company.

Greenfleet. (2012). “About our carbon forests.” available from: http://www.greenfleet.com.au/Greenfleets_forests/index.aspx (accessed 10 February 2014).

Harrington, C., Lane, R. \& Mercer, D. (2006). 'Learning conservation: the role of conservation covenants in landscape redesign at Project Hindmarsh, Victoria.” Australian Geographer 37(2) pp.187-209.

Hogan, A., Berry, H.L., Ng, S.P. \& Bode, A. (2010). Decisions made by farmers that relate to climate change. Canberra, Australia: Rural Industries Research and Development Corporation.

Holstein, J. A., \& Gubrium, J.F. (2003). Inside interviewing: new lenses, new concerns. edited by James A Holstein and Jaber F Gubrium. Thousands Oaks: Sage Publications.

Hunt, C. (2008). 'Economy and ecology of emerging markets and credits for bio-sequestered carbon on private land in tropical Australia.” Ecological Economics 66(2-3) pp. 309-18. 
Knapp, C. N., \& Fernandez-Gimenez, M.E. (2009). 'Knowledge in practice: documenting rancher local knowledge in northwest Colorado', Rangeland Ecology \& Management 62(6) pp. 500-509.

Lachapelle, P. R., \& McCool, S.F. (2012). 'The role of trust in community wildland fire protection planning', Society \& Natural Resources 25(4) pp. 321-35.

Lederer, M. (2011). 'From CDM to REDD+ — what do we know for setting up effective and legitimate carbon governance?', Ecological Economics 70(11) pp. 1900-1907.

Lemos, M. C., Agrawal, A., Eakin, H., Nelson, D. R., Engle, N. L., O, J. (2013). “Building Adaptive Capacity to Climate Change in Less Developed Countries.” Pp. 437-58 in Climate Science for Serving Society, edited by Ghassem R. Asrar and James W. Hurrell. Dordrecht: Springer Netherlands.

Liu, Z., Smith, W.J. \& Safi, A.S. (2013). 'Rancher and farmer perceptions of climate change in Nevada, USA', Climatic Change 122(1-2) pp. 313-27.

Mayer, R. C., Davis, J.H. \& F. \& Schoorman, D. (1995). 'An integrative model of organizational trust', Academy of Management Review 20(3) pp. 709-34.

Meadows, J., Herbohn, J. \& Emtage, N. (2013). 'Supporting cooperative forest management among small-acreage lifestyle landowners in southeast Queensland, Australia', Society \& Natural Resources 26(7) pp. 745-61. 
Measham, T. G. (2007). 'Building capacity for environmental management: local knowledge and rehabilitation on the Gippsland Red Gum plains.” Australian Geographer 38(2) pp. 145-59.

Mills, J. (2012). 'Exploring the social benefits of agri-environment schemes in England', Journal of Rural Studies 28(4) pp. 612-21.

Pannell, D. J., Marshall, G. R., Barr, N., Curtis, A., Vanclay, F. \& Wilkinson, R. (2006). 'Understanding and promoting adoption of conservation practices by rural landholders', Australian Journal of Experimental Agriculture 46(11) pp. 1407-24.

Pearce, David. (2005). 'Paradoxes in biodiversity conservation', World Economics 6(3) pp. 57-69.

Prell, C., Hubacek, K. \& Reed, M. (2009). 'Stakeholder analysis and social network analysis in natural resource management', Society \& Natural Resources 22(6) pp. 501-18.

Pretty, J. \& Ward, H. (2001). 'Social capital and the environment', World Development 29(2) pp. 209-27.

Putnam, R. D. (1993). Making Democracy Work: Civic Traditions in Modern Italy. Princeton, New Jersey: Princeton University Press.

QSR International. (2012). “NVIVO 10 for Windows.” from: http://www.qsrinternational.com/products_nvivo.aspx?utm_source=NVivo $+10+$ for $+\mathrm{Ma}$ c (accessed 27 May 2014). 
Rejesus, R. M., Mutuc-hensley, M., Mitchell, P.D.,mCoble, K.H. \& Knight, T.O. (2013). 'U.S. agricultural producer perceptions of climate change', Journal of Agricultural and Applied Economics 45(4) pp. 701-18.

Rice, P., \& Ezzy, D. (1999). Qualitative research methods: a health focus. Oxford University Press.

Riley, M. (2006). 'Reconsidering conceptualisations of farm conservation activity: the case of conserving hay meadows', Journal of Rural Studies 22(3) pp. 337-53.

Robertson, M. \& Murray-Prior, R. (2016). 'Five reasons why it is difficult to talk to Australian farmers about the impacts of, and their adaptation to, climate change', Regional Environmental Change 16(1) pp.189-98.

Rochecouste, J.F., Dargusch, P. Cameron, D \& Smith, C. (2015). 'An analysis of the socioeconomic factors influencing the adoption of conservation agriculture as a climate change mitigation activity in Australian dryland grain production', Agricultural Systems 135(2015) pp. 20-30.

Sabto, M. \& Porteous, J. (2011). 'Australia’s carbon farming initiative: a world first', ECOS (160). Retrieved (http://www.ecosmagazine.com/paper/EC10100.htm).

Safi, A.S., Smith, W.J. \& Liu, Z. (2012). 'Rural Nevada and climate change: vulnerability, beliefs, and risk perception', Risk Analysis: An Official Publication of the Society for Risk Analysis 32(6) pp. 1041-59. 
Sharp, E.A., Thwaites, R., Curtis, A. \& Millar, J. (2013). 'Trust and trustworthiness: conceptual distinctions and their implications for natural resources management.' Journal of Environmental Planning and Management 56(8) pp.1246-65.

Smith, P.F. (2008). 'Who’s planting what, where and why - and who's paying?', Landscape and Urban Planning 86(1) pp. 66-78.

Smith, J.W., Leahy, J.E., Anderson, D.H. \& Davenport, M.A. (2013). 'Community/Agency trust and public involvement in resource rlanning', Society \& Natural Resources 26(4) pp. $452-71$.

Sobels, J., Curtis, A. \& Lockie, S. (2001). 'The role of Landcare group networks in rural Australia: exploring the contribution of social capital', Journal of Rural Studies 17(3) pp. 265-76.

SoE. (2008). State of the environment Victoria 2008, Part 4 vegetation loss and land use change. Melbourne: State Government of Victoria.

SoE. (2013). Victoria: State of the environment report 2013, science policy people. Melbourne.

Stephenson, G. (2003). 'The somewhat flawed theoretical foundation of the extension service', Journal of Extension 41(4).

Sutherland, L. \& Burton, R.J.F.. (2011). 'Good farmers, good neighbours? the role of cultural capital in social capital development in a Scottish farming community', Sociologia Ruralis 51(3) pp. 238-55. 
Tarnoczi, T, J., \& Berkes, F. (2009). 'Sources of information for farmers’adaptation practices in Canada’s prairie agro-ecosystem', Climatic Change 98(1-2) pp. 299-305.

Torres, A. B., Marchant, R. Lovett, J.C., Smart, J.C.R. \& Tipper, R. (2010). 'Analysis of the carbon sequestration costs of afforestation and reforestation: agroforestry practices and the use of cost curves to evaluate their potential for implementation of climate change mitigation' Ecological Economics 69(3) pp. 469-77.

Trigger, D., Mulcock, J., Gaynor, A. \& Toussaint, Y. (2008). 'Ecological restoration, cultural preferences and the negotiation of 'nativeness' in Australia.” Geoforum 39(3) pp. 127383.

Trigger, D., Toussaint, Y. \& Mulcock, J. (2010). 'Ecological restoration in Australia: environmental discourses, landscape ideals, and the significance of human agency', Society \& Natural Resources 23(11) pp. 1060-74.

Uphoff, N. (1993). 'Grassroots organizations and NGOs in rural development: opportunities with diminishing states and expanding markets', World Development 21(4) pp. 607-22.

Van Noordwijk, M., Hoang, M.H., Neufeldt, H., Öborn Y.I, \& Atich, T. (2011). How trees and people can co-adapt to climate change: reducing vulnerability in multifunctional Landscapes. Nairobi: World Agroforestry Centre (ICRAF).

Whitmarsh, L. (2011). 'Scepticism and uncertainty about climate change: dimensions, determinants and change over time', Global Environmental Change 21(2) pp. 690-700. 
Willy, D.K. \& Holm-Müller, K. (2013). 'Social influence and collective action effects on farm level soil conservation effort in rural Kenya', Ecological Economics 90 pp. 94-103. 